\title{
Can I Trust You?
}

Citation for published version (APA):

Rusman, E., Van Bruggen, J., Sloep, P., Valcke, M., \& Koper, R. (2010). Can I Trust You? Profile Elements that Inform First Impressions of Trustworthiness in Virtual Project Teams. International Journal of Information

Technology Project Management (IJITPM), 3(1), 15-35. [2]. https://doi.org/10.4018/jitpm.2012010102

\section{DOI:}

10.4018/jitpm.2012010102

Document status and date:

Published: 18/01/2010

Document Version:

Peer reviewed version

\section{Document license:}

\section{BY-NC-ND}

Please check the document version of this publication:

- A submitted manuscript is the version of the article upon submission and before peer-review. There can be important differences between the submitted version and the official published version of record. People interested in the research are advised to contact the author for the final version of the publication, or visit the DOI to the publisher's website.

- The final author version and the galley proof are versions of the publication after peer review.

- The final published version features the final layout of the paper including the volume, issue and page numbers.

Link to publication

\section{General rights}

Copyright and moral rights for the publications made accessible in the public portal are retained by the authors and/or other copyright owners and it is a condition of accessing publications that users recognise and abide by the legal requirements associated with these rights.

- Users may download and print one copy of any publication from the public portal for the purpose of private study or research.

- You may not further distribute the material or use it for any profit-making activity or commercial gain

- You may freely distribute the URL identifying the publication in the public portal.

If the publication is distributed under the terms of Article 25fa of the Dutch Copyright Act, indicated by the "Taverne" license above, please follow below link for the End User Agreement:

https://www.ou.nl/taverne-agreement

Take down policy

If you believe that this document breaches copyright please contact us at:

pure-support@ou.nl

providing details and we will investigate your claim.

Downloaded from https://research.ou.nl/ on date: 26 Apr. 2023 


\title{
Can I trust you? - Personal profiling for a first impression of trustworthiness in virtual project teams
}

\author{
Ellen Rusman, Jan van Bruggen, Peter Sloep, Martin Valcke², Rob Koper \\ Open University of the Netherlands, The Netherlands \\ 2) Ghent University, Belgium
}

\begin{abstract}
This article reports what information members of a virtual project team specifically find important for the formation of an initial impression of the trustworthiness of their colleagues. Collaboration in virtual project teams heavily relies on interpersonal trust, for which perceived trustworthiness is an important determinant. We reviewed different trust-requiring and collaborative online environments to determine what information people have available through profiles. Taking this analysis as a starting point, a group of 226 students with experience in virtual project teams was questioned on signals they preferred to use to form an impression of trustworthiness. On the basis of the results obtained we have formulated several recommendations for the design of groupware environments. They pertain in particular to personal identity profiles.
\end{abstract}

Keywords: virtual project team, trust, trustworthiness, profile, online identity, impression formation, design, computer supported collaborative environments

\section{INTRODUCTION}

Virtual project teams are increasingly looked upon as a format for collaboratively solving complex and knowledge-intensive projects, within and between companies as well as in (inter)national non-profit organizations (Finholt, 2002; Perry, 2008). Several different notions of a virtual project team have been used in previous research, but here we understand it to be an organizational form which is assembled on an as-needed basis for the duration of a project and staffed by two or more members across spatial, temporal, cultural and/or organizational boundaries (Hung, 2004; Powell, 2004). Team members sporadically meet in person; communicate via ICT (e.g. email, chat, video-and/or audio-conferencing); they may not have a prior history of working together and may never meet in the future (Hung, 2004; S. Jarvenpaa \& Leidner, 1998).

Interpersonal trust between team members within such virtual project teams is broadly acknowledged to benefit collaboration and communication (Corbitt, 2004; Gambetta, 1988; S. Jarvenpaa, Knoll, \& Leidner, 1998; S. Jarvenpaa \& Leidner, 1998; S. L. Jarvenpaa, Shaw, \& 
Staples, 2004). The extent to which a person (the trustor) trust a team member (the trustee) to perform is the trustee's perceived trustworthiness (Hardin, 2002). Perceived trustworthiness is an important factor influencing interpersonal trust, next to a persons trust propensity, situational characteristics (e.g. perceived risk, task complexity, social control mechanisms) and the mood of a person at the time of trust formation (Castelfranchi \& Falcone, 1999; Riegelsberger, 2005; Rousseau, Sitkin, Burt, \& Camerer, 1998). In face-to-face settings, people construct a first impression of each other's trustworthiness based on different types of signals (perceived features of objects or events which indicate the presence of not observable properties) received through different routes (Bacharach \& Gambetta, 1997; Donath, 2006, 2007). A person can obtain information that signals such properties via direct encounters with another person as well as via reputational information via a connection (Olson \& Olson, 2000; Riegelsberger, 2005). In mediated settings these signals and routes are not abundantly available, but people nevertheless form a rather persistent impression base on the information they do collect (Cooper \& Bott, 1999; Hancock \& Dunham, 2001; Walther, 1995, 2005; Zolin, Hinds, Fruchter, \& Levitt, 2002). Although initial models for impression formation in mediated settings assumed a severely hampered and depersonalized communication process (Short, Williams, \& Christy, 1976; Siegel, Dubrovsky, Kiesler, \& McGuire, 1986), subsequent research has shown that only the process of forming an impression is slowed down (Walther, 1993, 1995, 1996). The cognitive need to form an impression of others is undiminished in mediated settings. People just use any type of information source in any way they can in order to form an initial impression (Laat \& Lally, 2003; Lea \& Spears, 1995; Liu, 2001; Postmes, Haslam, \& Swaab, 2005; Walther, 2005); all observations done hereafter are coloured by this perception, people even avoid to search for disconfirming information (Good, 1988; Petty \& Cacioppo, 1986).

Although extensive research has been done on the influence of information modality (e.g. text, video, audio) and richness (Daft \& Lengel, 1986) on trust formation (Bos, Olson, Gergle, Olson, \& Wright, 2002; Olson \& Olson, 2000), it remains unclear what specific information transmitted in these differently encoded messages 'does the trick' in professional settings. Several methods are used to support initial impression formation. Most make personal background and social information available, through story-telling, role-playing games, team-building exercises, personal profiles and elements in training. Even though they all have been found to support trust formation (Bacharach \& Gambetta, 1997; Feng, Lazar, \& Preece, 2004; Hung, 2004; Kanawattanachai \& Yoo, 2005; Rusman, Bruggen, Cörvers, Sloep, \& Koper, 2009; Zolin, Fruchter, \& Hinds, 2003), we don't really know what specific type of information people are looking for in professional contexts to determine whether someone is able, honest, incorruptible, consistent, responsible and so on (Macrae, 2001; Mayer, Davis, \& Schoorman, 1995; Rusman, Van Bruggen, Sloep, \& Koper, submitted). We do know that this first impression is especially important to accelerate trust formation in the initial phases of a virtual project team (S. L. Jarvenpaa et al., 2004). It thus is imperative to offer the 'right' and not too much information, to try and meet the need of virtual team members, thereby allowing them to function best.

In this article we present a study that aims to determine what specific information virtual project team members find beneficiary and useful to have available for trying to determine whether an individual team member is worthy of their trust in the initial phases of a virtual project team. One way to provide this info is through a personal identity profile, which contains static or dynamic information on a person's identity (Danis, 2000). Although some research has been done on 
profiles and their elements (Berlanga, Bitter-Rijpkema, Brouns, Sloep, \& Fetter, accepted; Boyd \& Heer, 2006; Lee, 2002), the use and function of the information elements available in these profiles, is assumedly to depend largely on the characteristics of the context they are implemented in. Information provided in privately-oriented, mediated contexts will be different than in professional contexts. In this study we initially look at both type of contexts and available information elements, as there is an indication that more private, personal oriented information is also important for people in a mediated professional context (Wilson, Straus, \& McEvily, 2006).

Our focus is furthermore on the type of information and not so much the modality of the media by which an impression of a team members' trustworthiness is formed. Although there is a difference in types of cues which can be transferred by different media, we assume the information content is the key determinant for the formation of trustworthiness. We expect that information signaling a persons professional ability, benevolence, accountability and so on, are most preferred by virtual team members. If we know what type of information virtual team members in general are looking for we can take this into account while designing artifacts or methods, such as a personal identity profile. Although individuals each use different, implicit personality theories to attribute characteristics to another person (Arnold, 1998), we here try to find their overlap when it comes to signaling trustworthiness in a professional setting.

Concluding, we seek an answer to the following questions:

1. What type of information is initially made available by system designers to allow the formation of a first impression of trustworthiness in existing trust-requiring and/or groupware environments?

2. What type of information users consider important for the formation of a first impression of trustworthiness in a virtual project team?

3. What type of information users consider as practical for collaboration in a virtual project team? 


\section{METHOD}

\section{Analysis of high-trust-requiring and groupware environments}

We first identified several online environments where people interact as individuals on an equal footing and where trust is an important factor for enabling this interaction. We selected environments where one may presume that people do not know each other yet and thus depend on information provided in a profile to form a first impression. We did not restrict our observations to professional environments only, as research on virtual project teams indicates that more personal and social-oriented information is likely to have a positive influence on trust formation. Table 1 represents the high-trust-requiring environments we selected for our observations. For each environment we specified with what aims people seek interaction and what risks they run, which then need to be overcome by trusting others in these environments.

\begin{tabular}{|c|c|c|c|}
\hline & Aim of individual & Risk & Observations in: \\
\hline Dating & $\begin{array}{l}\text { Find a suitable partner, } \\
\text { find a friend }\end{array}$ & $\begin{array}{l}\text { Encountering 'wrong' } \\
\text { people, leading to } \\
\text { harassments }\end{array}$ & $\begin{array}{l}\text { www.match.com } \\
\text { www.makefriendsonline.com }\end{array}$ \\
\hline Buying/selling & Buy or sell something & $\begin{array}{l}\text { selling: don't get } \\
\text { payment for your } \\
\text { goods; buying: don't } \\
\text { get your goods or get } \\
\text { rubbish }\end{array}$ & www.ebay.com \\
\hline Couch exchange & $\begin{array}{l}\text { Stay in the house of an } \\
\text { unknown host/host an } \\
\text { unknown visitor }\end{array}$ & $\begin{array}{l}\text { as guest: visit might } \\
\text { be unpleasant or even } \\
\text { dangerous; as host: } \\
\text { visitor might be } \\
\text { unpleasant, dangerous } \\
\text { or prone to theft }\end{array}$ & www.couchsurfing.com \\
\hline Social networking & $\begin{array}{l}\text { Link to people in a } \\
\text { network in order to } \\
\text { communicate, get } \\
\text { recommendations or get } \\
\text { informed on various } \\
\text { shared interests (e.g. } \\
\text { activities, photo's etc.) }\end{array}$ & $\begin{array}{l}\text { harassment by } \\
\text { unknown people } \\
\text { (connections in the } x^{\text {th }} \\
\text { grade) }\end{array}$ & $\begin{array}{l}\text { www.linkedin.com (network for } \\
\text { professionals); www.hyves.nl } \\
\text { (network for friends); } \\
\text { www.facebook.com (mixed user } \\
\text { group); http://elgq.net (educational } \\
\text { professionals) }\end{array}$ \\
\hline Recruitment & $\begin{array}{l}\text { Find suitable people for a } \\
\text { job; find a job }\end{array}$ & $\begin{array}{l}\text { Hire incompetent or } \\
\text { non-existing } \\
\text { employees; except a } \\
\text { job at an non-existent } \\
\text { and financial distrustful } \\
\text { organization }\end{array}$ & $\begin{array}{l}\text { www.monsterboard.nl; } \\
\text { www.reputator.net; www.aupair- } \\
\underline{\text { world.nl }}\end{array}$ \\
\hline
\end{tabular}

Table 1: Inventory of high-trust-requiring, online environments

We also analysed profiles within several groupware and professional environments (Table 2):

\begin{tabular}{lll}
\hline Environment & Description & References \\
\hline Moodle & $\begin{array}{l}\text { An open source course } \\
\text { management system designed to } \\
\text { help educators create online }\end{array}$ & http://moodle.org \\
\hline
\end{tabular}




\begin{tabular}{lll}
\hline & learning communities & \\
Future Learning Environment & $\begin{array}{l}\text { FLE is server software for computer } \\
\text { supported collaborative learning }\end{array}$ & $\underline{\text { http://fle3.uiah.fi }}$ \\
EGroupware & Free enterprise ready groupware & $\underline{\text { http://www.egroupware.org }}$ \\
PhPGroupware & Multi-user groupware suite & $\underline{\text { http://www.phpgroupware.org }}$ \\
Pexpi & $\begin{array}{l}\text { Personal expertise template used } \\
\text { within several OUNL distance }\end{array}$ & $\begin{array}{l}\text { (Berlanga et al., accepted; Ogg et al., } \\
\text { courses } \\
\text { 2004; Rusman et al., 2009; Rusman, } \\
\text { Bruggen, \& Koper, 2007) }\end{array}$ \\
& $\begin{array}{l}\text { Template for employee overview } \\
\text { within OUNL (internal view) }\end{array}$ & $\begin{array}{l}\text { http://www.ou.nl/eCache/DEF/85.html } \\
\text { (external view) }\end{array}$ \\
\hline
\end{tabular}

Table 2: Overview of groupware and collaborative environments

Within each of these 17 environments we identified the information elements which were available in the personal identity profiles and could be used to form a first impression of trustworthiness. Thus, we obtained a list with all information elements specific to each of these different contexts (Appendix A), as well as a count of the commonly used information elements across these environments (see 'results' section).

\section{Survey on importance of information for a first impression of trustworthiness}

Using the list with information elements obtained by observing high-trust-requiring environments as our starting point, using a survey by means of a structured questionnaire at the Ghent University, Belgium. The objective of this survey was to determine which information elements the respondents consider most important for the formation of a first impression of trustworthiness in the context of virtual project teams.

\section{Participants}

Data were collected among bachelor level students, enrolled in the Educational Sciences programme at the Ghent University, as a part of their acquaintance with doing research. Thus, a convenience sample of 226 respondents (mean age $=18,2$ years, $S D=1,85$ ) was obtained, 93\% of which were female and $7 \%$ male. $99 \%$ of the respondents had previous experience with collaboration in a f2f project team, either in a (part-time) job or during their study. $95 \%$ had previous experience with collaboration in a virtual project team, probably earlier within the curriculum. 88\% of the respondents had experience with online conversations with people they had never met before. The majority of the online conversations took place via text-based media only, either via sec chat and/or e-mail (78\%) or in combination with SMS (9\%).

\section{Materials}

The questionnaire contained twelve open, as well as close-end questions in the respondents native tongue (Dutch). Open-ended questions referred to background variables of respondents, such as age, as well as the description of experiences and explanation of responses. Participants were also asked in an open question to think of at least 15 information elements they would value high to form a first impression of a virtual project team member. Here we report on the results of the subsequent close-ended questions only (see appendix A for an overview of relevant 
questions and answer options). These questions referred mainly to rating the importance of potentially available information elements in a pre-defined list. Although the rating of an information element could each be seen as a separate question, we consider them part of one general question.

\section{Procedure}

Preceding the completion of the questionnaire, participants received a short presentation that clarified our definition of virtual project teams, showed examples of them, discussed the role of interpersonal trust for collaboration and the objectives of the questionnaire. We also explained the way items had to be scored, which was again described in the questionnaire. Respondents were told that the responses to this questionnaire would be kept anonymous and that it would take about 30 minutes to complete the close-end questions of the questionnaire.

Prior to rating the information elements, respondents were prompted by a scenario in the questionnaire that described them as a member of a new European project, which required them to collaborate in a virtual project team (Appendix A). They were asked to imagine that they were part of this virtual team and told that, within two weeks from the start of the project, they had to form a first impression of their team members' trustworthiness. They could determine what information (from a pre-defined list) they would have available within the profiles of their team members. This could be done by rating the information on importance for forming a first impression of trustworthiness. Respondents were then asked to rate information elements on a 5point Likert scale: (1) Definitely not important, (2) Not important, (3) Neutral, (4) Important, (5) Definitely important.

In addition, respondents were also asked to indicate per information element if they thought the information would be of practical use for collaboration in a virtual project team.

\section{RESULTS}

\section{Analysis}

Based on the analysis, we extracted a list of 157 information elements that were available in profiles within high-trust-requiring online environments as well as groupware environments. This list could be divided in static (unchangeable) as well as dynamic (changeable, based on behaviour) information elements (Danis, 2000). All elements became part of the answer options of the survey (Appendix A). We also checked which information elements were available across eight or more environments, thus indicating what designers commonly considered important for the representation of identity as well as for impression formation of their users. This resulted in the following list with overlapping elements across these environments:

- $\quad$ Name (first and surname)

- Pseudonym (alias/display name)

- Photo

- Personal description/about me

- $\quad$ Age/date of birth

- $\quad$ Reference to personal URL (blog,website, homepage) 
- Contact data (business/private)

- Contact method

- Location data (business/private)

- Occupation/function/position/role

- Company/organization/employer

- Education

- Interests (private/professional)

- Languages (level, preferred language for communication)

- Testimonials (references, info from others about person)

These information elements largely overlap with the information elements found by Berlanga et.al (accepted) while looking at three well-known social network sites.

\section{Survey}

For all information elements, their mean importance and standard deviation was calculated based on the respondents' scores. Missing values were not taken into account. Mean values equal or higher then 4 were considered as an indication that they were commonly considered important for the formation of a first impression of trustworthiness within the group, whereas mean values equal or lower then 2 were considered unimportant. We rounded all figures to two decimals. Most SD's were less than 1, still either indicating scores of 'neutral or definitely important' in case of the important elements and 'definitely not important or neutral' in case of the least important elements. Thus we identified a list with 23 information elements generally considered important for the formation of a first impression of trustworthiness. Tables 3 and 4 provide an overview of the most and least important information elements.

Table 3: Means and standard deviations of importance of information elements with scores $\geq 4$

((1) Definitely not important, (2) Not important, (3) Neutral, (4) Important, (5) Definitely important))

\begin{tabular}{|c|c|c|c|c|}
\hline $\begin{array}{l}\text { Information element } \\
\text { (+ code) }\end{array}$ & Description & $\mathbf{N}$ & Mean & SD \\
\hline Personal motivation for project & & 221 & 4,52 & ,58 \\
\hline Ideas for project & $\begin{array}{l}\text { Thoughts, opinions, insights and plans } \\
\text { for project }\end{array}$ & 221 & 4,51 & ,64 \\
\hline $\begin{array}{l}\text { Reason why you are selected to } \\
\text { participate in project }\end{array}$ & & 222 & 4,47 & ,57 \\
\hline Expectation of project & & 223 & 4,35 & ,71 \\
\hline $\begin{array}{l}\text { I would like to work in the following } \\
\text { type of situation(s) ..., because ... }\end{array}$ & $\begin{array}{l}\text { Preference and motivation for working } \\
\text { in specific situation(s) within the } \\
\text { project }\end{array}$ & 220 & 4,34 & ,66 \\
\hline $\begin{array}{l}\text { I would like to work on this part of } \\
\text { the project ..., because ... }\end{array}$ & $\begin{array}{l}\text { Preference and motivation for working } \\
\text { on a specific part of the project }\end{array}$ & 222 & 4,32 & ,77 \\
\hline Project aims & $\begin{array}{l}\text { That which someone strives for within } \\
\text { the project from a personal belief and } \\
\text { ambition }\end{array}$ & 224 & 4,32 & ,81 \\
\hline Project time capacity & $\begin{array}{l}\text { Number of hours someone has } \\
\text { available for the work that needs to be }\end{array}$ & 218 & 4,32 & ,81 \\
\hline
\end{tabular}




\begin{tabular}{|c|c|c|c|c|}
\hline Ways I want to contribute to project & $\begin{array}{l}\text { done within the project } \\
\text { Ideas about potential personal } \\
\text { contributions to the project }\end{array}$ & 216 & 4,31 & ,60 \\
\hline Previous work experience & List of jobs and functions held & 219 & 4,26 & ,76 \\
\hline Availability during project & $\begin{array}{l}\text { Insight in availability during project, } \\
\text { e.g. by showing regular office } \\
\text { days/hours, planned holidays and/or } \\
\text { planned time spans to work on the } \\
\text { project }\end{array}$ & 219 & 4,24 & ,83 \\
\hline Personality traits & $\begin{array}{l}\text { Summary of important properties and } \\
\text { personality traits of a person }\end{array}$ & 222 & 4,24 & ,85 \\
\hline $\begin{array}{l}\text { Description of relevant work } \\
\text { experience }\end{array}$ & $\begin{array}{l}\text { Particulars and characteristics of } \\
\text { previously acquired work experience in } \\
\text { relation to for the project indispensable } \\
\text { competencies }\end{array}$ & 223 & 4,23 & ,69 \\
\hline Description education/training & $\begin{array}{l}\text { Particulars and characteristics of } \\
\text { educational programs/courses followed } \\
\text { in relation to for the project } \\
\text { indispensable competencies }\end{array}$ & 223 & 4,20 & ,84 \\
\hline Managerial work experience & Previous experience with management & 218 & 4,18 & ,76 \\
\hline Expertise & $\begin{array}{l}\text { Areas someone is able and specialized } \\
\text { in }\end{array}$ & 217 & 4,18 & ,84 \\
\hline Expectation of others within project & $\begin{array}{l}\text { Anticipation on future behavior, rules } \\
\text { of conduct, contributions of and } \\
\text { interactions with team members within } \\
\text { project }\end{array}$ & 217 & 4,16 & ,74 \\
\hline Language and language proficiency & & 214 & 4,09 & ,84 \\
\hline Appointments made and follow up* & $\begin{array}{l}\text { Overview of appointments, with whom } \\
\text { they were made, and the status of } \\
\text { follow up }\end{array}$ & 219 & 4,09 & ,87 \\
\hline Contact data (office) & $\begin{array}{l}\text { For example e-mail, (mobile) phone, } \\
\text { fax, address (office nr., street, zipcode, } \\
\text { skype/msn/ICQ/Yahoo, pager }\end{array}$ & 215 & 4,06 & 1,05 \\
\hline $\begin{array}{l}\text { Task list with all deadlines, planned } \\
\text { and realized tasks within project }\end{array}$ & $\begin{array}{l}\text { Overview of all tasks, deadlines and } \\
\text { status of tasks a project member is } \\
\text { responsible for }\end{array}$ & 219 & 4,05 & ,84 \\
\hline Preference for role within project & $\begin{array}{l}\text { Preferred role with related tasks and } \\
\text { responsibilities within the project }\end{array}$ & 217 & 4,03 & 81 \\
\hline $\begin{array}{l}\text { Preferred language for } \\
\text { communication within project }\end{array}$ & & 213 & 4,00 & 95 \\
\hline
\end{tabular}

* dynamic information element 
Table 4: Means and standard deviations of importance of information elements scores $\leq \mathbf{2}$

((1) Definitely not important, (2) Not important, (3) Neutral, (4) Important, (5) Definitely important))

\begin{tabular}{llllc}
\hline $\begin{array}{l}\text { Information element } \\
\text { (+ code) }\end{array}$ & Description & N & Mean & SD \\
\hline Pseudonym/alias & & 220 & 2,05 & 1,09 \\
Body art & & 223 & 2,01 & 1,14 \\
Daily eating habits & Favorite place of a person & 225 & 1,96 & 1,03 \\
Favorite spot & Figure and pose of a person & 220 & 1,85 &, 98 \\
Physical stature & & 223 & 1,81 &, 97 \\
Domestic animal/pet & & 224 & 1,68 &, 98 \\
Hair & e.g. color, model, length & 224 & 1,60 &, 87 \\
Eyes & e.g. color, shape & 224 & 1,57 &, 87 \\
Weight & & 224 & 1,49 &, 70 \\
Length & & 223 & 1,47 &, 70 \\
Sign of the zodiac & & 220 & 1,46 &, 87 \\
\hline
\end{tabular}

We also determined the scores for the information elements which were considered commonly as practical for collaboration, employing a threshold of 0,4 for inclusion. Table 5 provides an overview of the identified information elements.

Table 5: Means and standard deviations of practical usefulness of information elements scores $\geq .40$ ((0) not useful, (1) useful)

\begin{tabular}{llllc}
\hline $\begin{array}{l}\text { Information element } \\
\text { (+ code) }\end{array}$ & Description & N & Mean & SD \\
\hline Availability during project & $\begin{array}{l}\text { Insight in availability during project, } \\
\text { e.g. by showing regular office } \\
\text { days/hours, planned holidays and/or } \\
\text { planned time spans to work on the } \\
\text { project }\end{array}$ & 225 &, 44 &, 50 \\
Contact data (office) & $\begin{array}{l}\text { For example e-mail, (mobile) phone, } \\
\text { fax, address (office nr., street, zipcode, } \\
\text { skype/msn/ICQ/Yahoo, pager } \\
\text { Number of hours someone has } \\
\text { available for the work that needs to be }\end{array}$ & 221 &, 434 &, 50 \\
Project time capacity & ,42 & & & \\
\hline
\end{tabular}




\begin{tabular}{|c|c|c|c|c|}
\hline $\begin{array}{l}\text { Preferred medium for contact during } \\
\text { project }\end{array}$ & $\begin{array}{l}\text { done within the project } \\
\text { Personal preference for contact media, } \\
\text { e.g. via mail, skype, etc. }\end{array}$ & 221 & ,42 & ,49 \\
\hline Local time at location of team member ${ }^{*}$ & $\begin{array}{l}\text { Time at the residence of a team } \\
\text { member. Through time zones, time is } \\
\text { dependent on location on the globe. }\end{array}$ & 226 & ,41 & ,49 \\
\hline Language and language proficiency & & 223 & ,40 & ,49 \\
\hline
\end{tabular}

\section{CONCLUSION AND DISCUSSION}

The current study provides insight in what information elements are commonly perceived as important for the formation of a first impression of trustworthiness. We arrived at this list by querying a group of students with virtual project team experience whom we enlisted in a 'simulated' virtual project team. We assumed an equal and not a hierarchical relation between project team members, as the latter might affect the type of information a person is looking for (Albrecht, 2002; Schoorman, Mayer, \& Davis, 2007). Our study was carried out by means of convenience sample, primarily containing young Belgian female students. Although this may restrict the applicability of the outcomes, the communality between a large number of respondents at least suggests that results are applicable more broadly and partly transferable to real virtual project teams in countries with a similar culture.

Our first question focused on the identification of information which is made available by system designers within profiles across 17 , very different, trust-requiring situations. The results show 15 information elements which are universally present across those contexts, as well as 157 very diverse information elements, ranging from information on ones zodiac sign to professional interests and activities (Appendix A). An analysis of the results reveals that the type of information elements which are seen as important by designers largely depend on the context of the trust-requiring situations and the aim for which the environment is developed; the importance of an element is dependent on the context in which it is supplied. However, restricting ourselves to information elements available within groupware and professional environments only, still a wide range of elements was made available. This indicates that designers hold different views, implicit as they may be, on the information elements users need to interact within a trustrequiring professional context. The remaining common information elements which were available across more than eight environments are largely for identification and practical purposes, with the exception perhaps of such elements as 'personal description', 'occupation', 'education', 'interests' and 'testimonials'. Overall, this analysis provided a basis for the second part of the study as well as an indication that it would indeed be useful to look at a common preference for particular information elements among virtual project team members.

The second question focused on what type of information virtual project team members see as important for the formation of a first impression of trustworthiness in a professional context, independent of the type of medium by which they are transmitted. Making use of the wisdom of 
a crowd a list of 23 important information elements could be identified, the selection having been made on content-related, not media-related, considerations only (Table 3). Also information elements, for example one's zodiac sign or pet, which were deemed relevant in another context such as dating, were identified as irrelevant for the formation of an initial impression of trustworthiness within a professional collaborative context (Table 4). Looking at the resulting list of 23 information elements, virtual project team members indeed seem to be specifically interested in information that signals characteristics specific to trustworthiness in a professional context, such as his or her ability, motivation, availability, responsibility and so on. It seems to be important to take the professionals conceptual model of trustworthiness into account while determining what information will be made available within virtual project team environments. Respondents seem to simply assume that basic information on the identity of the other, such as a name, photo etc., are available, since they do not indicate these information elements as important for the determination of trustworthiness. Most strikingly, the list with preferred information elements is almost completely different to the list with information elements provided by the system designers. Looking at the list it is also striking that only few dynamic information elements, that display behaviour, are selected and seen as important for the formation of a first impression of trustworthiness. This corresponds to what we found in a first explorative study (Rusman et al., 2009), in which we researched whether the availability of information in a profile positively affected the formation of a trustworthiness impression. There and then we determined what information was made available in the profile and results indicated that the availability of information helped people to form an impression, as well as aided their collaboration. In this study, qualitative data indicated that people were divided over the display of dynamic data, mentioning pros as well as cons, such as a sense of shared responsibility as well as the sense that 'big brother is watching you'. In the current study we did not specifically ask them to explain their responses in relation to the dynamic information. The de-emphasis of dynamic information could also be related to the fact that our window of research only covered the first two weeks only. In such a short period of time little dynamic information based on user behaviour has become available.

Our third question focused on what information virtual project team members commonly see as practical for collaboration. Here we see that the results are almost all related to an insight in the availability of the other, and in the language and methods with which people can contact each other (Table 5). Some of the information elements overlap with the important information elements from the previous question. Individual information elements can thus have multiple functions.

Looking at the results based on a review of existing trust-requiring contexts and the results based on the selection of users, we see a clear difference between what information designers designed for and the preference of virtual project team members. Furthermore, it is clear context matters. The difference found between information offered and information needed to form an impression of trustworthiness within virtual project teams clearly indicates groupware designers how to adapt their design. It also helps virtual project team leaders to design activities and guidelines that foster a virtual teams performance. The information elements found across all environments could be seen as a kind of baseline, complemented with information elements which matter to the formation of a first impression of trustworthiness. 
Results also indicate that, looking at the most important information elements, virtual project team members indeed seem to look specifically at signals that indicate professional trustworthiness properties in relation to the project at hand, such as ability, motivation, responsibility. Although we expected that more personally oriented information would be important for initial impression information, the results do not confirm this expectation. When more personal information is needed, it is in almost all cases related to the professional context. Examples are one's preference and motivation or one's project related personal beliefs and ambitions. It would be interesting to see whether a relation between the preferred information elements and a common conceptual model of professional trustworthiness could be made, for example based on the analysis of the open answers in the questionnaire within the 'simulated' virtual project team. It could be that some information elements provide information for more than one conceptual category, for example one's education could say something about one's ability as well as one's consistency and responsibility, thus providing more signals within one information element. Also, it would be useful to research whether there is a difference between a 'sender' presenting trustworthiness related information and a 'receiver' looking for information, as now we have only looked at the information needs of a receiver. In the future we will apply our insights to actual, rather than 'simulated' virtual teams, as a means to further validate our results empirically.

\section{REFERENCES}

Albrecht, S. L. (2002). Perceptions of Integrity, Competence and Trust in Senior Management as Determinants of Cynicism Toward Change. Public Administration and Management: An Interactive Journal 7(4), 320-343.

Arnold, J., Cooper, C.L., Robertson, I.T. (1998). Work psychology. Understanding human behaviour in the workplace. (3 ed.). Essex: Financial Times Professional Limited.

Bacharach, M., \& Gambetta, D. (1997). Trust in signs. In K. S. Cook (Ed.), Trust in Society. (pp. 148-184.). New York.: Russell Sage Foundation. .

Berlanga, A. J., Bitter-Rijpkema, M. E., Brouns, F., Sloep, P. B., \& Fetter, S. (accepted). Personal profiles: Enhancing Social Interaction in Learning Networks. International Journal of Web based Communities.

Bos, N., Olson, J., Gergle, D., Olson, G., \& Wright, Z. (2002). Effects of Four Computer-Mediated Communications Channels on Trust Development. Paper presented at the CHI 2002.

Boyd, D., \& Heer, J. (2006). Profiles as Conversation: Networked Identity Performance on Friendster. Paper presented at the 39th Hawaii International Conference on System Sciences, Hawaii.

Castelfranchi, C., \& Falcone, R. (1999). Trust is more than subjective probability: mental components and sources of trust. Retrieved 22 March, 2006

Cooper, A., \& Bott, M. W., J. (1999). Influence of Expectancies and Experience on Impression Formation. Journal of Pscyhological Inquiry, 4, 21-24.

Corbitt, G., Gardiner; L., Wright, L. (2004). A comparison of team developmental stages, trust and performance for virtual versus face-to-face teams. Paper presented at the Proceedings of the 37th Hawaii International Conference on System Sciences, Hawaii. 
PREPRINT

Daft, R. L., \& Lengel, R. H. (1986). Organizational Information Requirements, Media Richness and Structural Design. Management Science, 32(5), 554-571.

Danis, C. M. (2000). Extending the concept of awareness to include static and dynamic person information. SIGGroup Bulletin, 21(no.3.), 59-62.

Donath, J. (2006, 15 february 2006). Signals, cues and meaning. Retrieved august, 2006, from http://smg.media.mit.edu/classes/IdentitySignals06/SignalingDraft.pdf

Donath, J. (2007). Signals in social supernets. Journal of Computer-Mediated Communication, 13(1), article 12.

Feng, J., Lazar, J., \& Preece, J. (2004). Empathy and online interpersonal trust: a fragile relationship. Behaviour and information technology.

Finholt, T. A. (2002). Collaboratories. Annual Review of Information Science and Technology, 36, 73-107.

Gambetta, D. (1988). Trust: making and breaking cooperative relations. Oxford: Basil Blackwell.

Good, D., Gambetta, Diego. (1988). Individuals, Interpersonal Relations, and Trust. In Trust: Making and breaking cooperative relations (pp. 31-48): Oxford and New York:

Blackwell.

Hancock, J. T., \& Dunham, P. J. (2001). Impression Formation in Computer-Mediated Communication Revisited. Communication research, 28(3), 325-347.

Hardin, R. (2002). Trust and trustworthiness. New York: Russell Sage Foundation.

Hung, Y. C., Dennis, A.R, Robert, L. (2004). Trust in Virtual Teams: Towards an Ingegrative Model of Trust Formation. Paper presented at the 37th Hawaii International Conference on System Sciences, Hawaii.

Jarvenpaa, S., Knoll, K., \& Leidner, D. (1998). Is Anybody Out There?: The Development of Trust in Virtual Teams. Journal of Management Information Systems Vol. 14(No.4), pp. 29-64.

Jarvenpaa, S., \& Leidner, D. (1998). Communication and trust in global virtual teams. JCMC, 3(4).

Jarvenpaa, S. L., Shaw, T. R., \& Staples, D. S. (2004). Toward Contextualized Theories of Trust: The Role of Trust in Global Virtual Teams. Information Systems Research, 15(3), 250-264.

Kanawattanachai, P., \& Yoo, Y. (2005). Dynamic nature of trust in virtual teams. Sprouts: Working papers on Information Environments, systems and organizations, 2(2), 41-58.

Laat, d., M., \& Lally, V. (2003). Complexity, theory and praxis: Researching collaborative learning and tutoring processes in a networked learning community. Instructional science, 31, 7-39.

Lea, M., \& Spears, R. (1995). Love at first byte? Building personal relationships over computer networks. In J. T. Wood \& S. Duck (Eds.), Understudied Relationships: Off the Beaten Track. Newbury Park: CA: Sage.

Lee, A., Girgensohn, A., Zhang, J. (2002). Collective construction of facets of a group identity. Retrieved June, 2006, from http://www.webcollab.com/alee/portfolio/

Liu, Y., Ginther, D. (2001). Managing Impression Formation in Computer-Mediated Communication. Educause Quarterly, 3, 50-54.

Macrae, C. N., Bodenhausen, G.V. (2001). Social cognition: categorical person perception. British Journal of Psychology, 92, 239-255.

Mayer, R. C., Davis, J. H., \& Schoorman, D. (1995). An integrative model of organizational trust. Academy of management review, 20(3), 709-734.

Ogg, H., van Elk, L., Hondius, A., Stofberg, A., Aa van, P., Bitter, M., et al. (2004). Samenwerkend leren digitaal Ondersteund. Handboek. Utrecht: Stichting Digitale Universiteit.

Olson, G. M., \& Olson, J. S. (2000). Distance Matters. Human-Computer Interaction, 15(2\&3), 139-178.

Perry, B. (2008). Virtual Teams Now a Reality. Two out of Three Companies Say They Will Rely More on Virtual Teams in the Future. Retrieved 5 October 2009, from http://www.i4cp.com;

http://www.pr.com/press-release/103409 
PREPRINT

Petty, R. E., \& Cacioppo, J. T. (1986). Communication and Persuasion: Central and Peripheral Routes to Attitude Change: Springer-Verlag, New York.

Postmes, T., Haslam, S. A., \& Swaab, R. I. (2005). Social influence in small groups: An interactive model of social identity formation. European Review of Social Psychology, 16, 1-42.

Powell, A., Piccoli, G., Ives, B. (2004). Virtual teams: a review of current literature and directions of future research. The database for advances in Information Systems, 35(1), 6-36.

Riegelsberger, J. (2005). Trust in mediated interactions. University College London, London.

Rousseau, D. M., Sitkin, S. B., Burt, R. S., \& Camerer, C. (1998). "Not so different after all: a crossdiscipline view of trust". Academy of Management Review, 23(3), 393-404.

Rusman, E., Bruggen, v., J., Cörvers, R., Sloep, P., \& Koper, R. (2009). From pattern to practice: Evaluation of a design pattern fostering trust in virtual teams. Computers in Human Behaviour, 25(5), 10101019.

Rusman, E., Bruggen, v., J., \& Koper, R. (2007). From pattern to practice: evaluation of a design pattern fostering trust in virtual teams. Conference workshop on CSCL design patterns, from http://cosy.ted.unipi.gr/Papers.html

Rusman, E., Van Bruggen, J., Sloep, P., \& Koper, R. (submitted). Fostering trust in virtual project teams: towards a design framework grounded in a TrustWorthiness Antecedent (TWAN) schema.

Schoorman, F. D., Mayer, R. C., \& Davis, J. H. (2007). An integrative model of organizational trust: past, present and future. Academy of Management Review

32(2), 344-354.

Short, J., Williams, E., \& Christy, B. (1976). The social psychology of telecommunications. London: John Wiley.

Siegel, J., Dubrovsky, V., Kiesler, S., \& McGuire, T. (1986). Group processes in computer-mediated communication. Organizational Behavior and Human Decision Processes, 37, 157-187.

Walther, J. B. (1993). Impression development in computer-mediated interaction. Western Journal of Commmunication, 57, 381-398.

Walther, J. B. (1995). Relational Aspects of Computer-mediated Communication: Experimental Observations over Time. Organization Science, 6(2), 186-203.

Walther, J. B. (1996). Computer-mediated communication: Impersonal, interpersonal, and hyperpersonal interaction. Communication research, 23, 3-43.

Walther, J. B. (2005). The rules of virtual groups. Paper presented at the Proceedings of the 38th Hawaii International Conference on System Sciences, Hawaii.

Wilson, J. M., Straus, S. G., \& McEvily, B. (2006). All in due time: The development of trust in computermediated and face-to-face teams. Organizational Behavior \& Human Decision Processes, 99(1), 16-33.

Zolin, R., Fruchter, R., \& Hinds, P. (2003). Communication, Trust \& Performance: The Influence of Trust on Performance in A/E/C Cross-functional, Geographically Distributed Work. Stanford: Stanford university.

Zolin, R., Hinds, P. J., Fruchter, R., \& Levitt, R. E. (2002). Trust in Cross-functional, global teams. CIFE 


\section{APPENDIX A - CONDENSED VERSION OF QUESTIONNAIRE}

\section{General}

1. What is your gender? (male/female)

2. What is your age? (... year)

3. Do you have experience with collaboration within a face to face project team within work-or study related settings? ( $\mathrm{n} / \mathrm{y})$

4. Do you have experience with collaboration within a virtual project team within workor study related settings? (n/y)

5. Do you have experience with online conversations with people you have never met face to face? (n/y). (y): These conversations were primarily mediated via: text (chat, e-mail); audio conferences; videoconferences; SMS; other, namely

6. Did you meet someone face to face which you previously only knew online? (n/y) If so, was this person face to face very differently then you had until them imagined him/her to be? In which way(s)?

\section{Imagine:}

You recently became a member of an international virtual team within an European financed project. This virtual team collaborates independent from time, place, organization and country via a virtual project space during the lifespan of the project. Within the project you have to jointly deliver a product. You work with people from different organizations (companies, governmental and non-profit), with each of them specialized in a certain knowledge domain and with certain discipline-related skills. In order to develop a product meeting high quality standards it is important that you all integrate this specialized knowledge and use your skills. To finish this product in time you are strongly dependent on each other. For you personally the success of this project is important as well. You don't know the people you are going to collaborate with and it is not possible to meet each face to face within this project.

You want to form an impression of the trustworthiness of your different team members within the first two weeks of the project. Within the project this is arranged by making profile information from each team member available. You can determine yourself which information you would like to have available within these profiles.

1. Which profile information is important to form a first impression of the trustworthiness of a virtual project team member? Think of at least 15 information elements that are important for you to form this impression .(open question).

\section{Imagine:}

You are in the same situation as just described. Several people have already thought about different types of information elements which could become available within a profile and have listed them. You may also determine what type of information will be made available within prestructured profiles. All team members are asked to indicate per listed information element:

2. The importance of having this information element available in a profile to form a first impression of trustworthiness of a team member within the first two weeks of a project. 
Indicate your choice by marking: (1) Definitely not important, (2) Not important, (3) Neutral, (4) Important, (5) Definitely important

3. The practical usefulness of having this information element available in a profile to collaborate in a virtual project team.

Check the box if you think this element would be practically useful.

Information elements listed subsequently:

(without descriptions provided in the original questionnaire)

Static information (116 information elements)

\begin{tabular}{|c|c|c|c|c|}
\hline Title/degree & Location (private) & Zodiac & $\begin{array}{l}\text { Ways I want to } \\
\text { contribute to } \\
\text { project }\end{array}$ & $\begin{array}{l}\text { Hates ... during } \\
\text { work }\end{array}$ \\
\hline Name & Location (work) & $\begin{array}{l}\text { Sports and } \\
\text { condition }\end{array}$ & $\begin{array}{l}\text { Expectation of } \\
\text { others within } \\
\text { project }\end{array}$ & $\begin{array}{l}\text { Relevant } \\
\text { experience and } \\
\text { skills from } \\
\text { previous projects }\end{array}$ \\
\hline Surname & $\begin{array}{l}\text { Personal } \\
\text { device/slogan }\end{array}$ & $\begin{array}{l}\text { Ethnic } \\
\text { background }\end{array}$ & Religion & Travel experience \\
\hline Pseudonym/alias & $\begin{array}{l}\text { Terms of } \\
\text { employment }\end{array}$ & $\begin{array}{l}\text { Personal interests } \\
\text { (hobbies/activities }\end{array}$ & $\begin{array}{l}\text { Example cultural } \\
\text { background and } \\
\text { customs }\end{array}$ & Publications \\
\hline Date of birth & Job status & $\begin{array}{l}\text { Professional } \\
\text { interests and } \\
\text { activities }\end{array}$ & $\begin{array}{l}\text { Language and } \\
\text { language } \\
\text { proficiency }\end{array}$ & Awards \\
\hline Nationality & $\begin{array}{l}\text { Previous work } \\
\text { experience }\end{array}$ & Employer & $\begin{array}{l}\text { Preferred } \\
\text { language for } \\
\text { communication } \\
\text { within project }\end{array}$ & Media experience \\
\hline $\begin{array}{l}\text { Personality } \\
\text { traits }\end{array}$ & $\begin{array}{l}\text { Managerial work } \\
\text { experience }\end{array}$ & Branch/sector & $\begin{array}{l}\text { Political } \\
\text { viewpoint }\end{array}$ & $\begin{array}{l}\text { Presentation } \\
\text { experience }\end{array}$ \\
\hline Place of birth & $\begin{array}{l}\text { Description } \\
\text { education/training }\end{array}$ & Department & $\begin{array}{l}\text { Philosophical } \\
\text { viewpoint }\end{array}$ & $\begin{array}{l}\text { Teach, learn, } \\
\text { preach an useful } \\
\text { experience }\end{array}$ \\
\hline $\begin{array}{l}\text { Raised } \\
\text { in/hometown }\end{array}$ & Drivers license & Salary & $\begin{array}{l}\text { Amazing } \\
\text { experience/live } \\
\text { event }\end{array}$ & $\begin{array}{l}\text { Type of people I } \\
\text { love }\end{array}$ \\
\hline Gender & $\begin{array}{l}\text { I would like to } \\
\text { work on this part } \\
\text { of the project..., } \\
\text { because ... }\end{array}$ & $\begin{array}{l}\text { Name of } \\
\text { function/role/posit } \\
\text { ion within } \\
\text { organization }\end{array}$ & $\begin{array}{l}\text { Favorite links } \\
\text { (professional) }\end{array}$ & $\begin{array}{l}\text { Worst project } \\
\text { experience }\end{array}$ \\
\hline Formal & I would like to & Description of & Favorite links & Best project \\
\hline
\end{tabular}




\begin{tabular}{|c|c|c|c|c|}
\hline photo’s & $\begin{array}{l}\text { work in the } \\
\text { following type of } \\
\text { situation(s) ..., } \\
\text { because ... }\end{array}$ & $\begin{array}{l}\text { your } \\
\text { function/role/posit } \\
\text { ion }\end{array}$ & (private) & experience \\
\hline $\begin{array}{l}\text { Informal } \\
\text { photo's }\end{array}$ & $\begin{array}{l}\text { Professional } \\
\text { website/homepage }\end{array}$ & $\begin{array}{l}\text { Motivation for } \\
\text { your } \\
\text { function/role/posit } \\
\text { ion }\end{array}$ & $\begin{array}{l}\text { Professional } \\
\text { references } \\
\text { (articles) }\end{array}$ & Writing style \\
\hline Length & $\begin{array}{l}\text { Personal } \\
\text { website/homepage }\end{array}$ & Ideas for project & Memberships & $\begin{array}{l}\text { Correct written } \\
\text { and oral language } \\
\text { use }\end{array}$ \\
\hline Weight & $\begin{array}{l}\text { Willingness to } \\
\text { travel for project }\end{array}$ & Personal aims & $\begin{array}{l}\text { Social network } \\
\text { (friends/connectio } \\
\text { ns) }\end{array}$ & Future plans \\
\hline $\begin{array}{l}\text { Physical } \\
\text { stature }\end{array}$ & $\begin{array}{l}\text { Contact data } \\
\text { (work) }\end{array}$ & Career aims & $\begin{array}{l}\text { Degree of } \\
\text { relationship }\end{array}$ & $\begin{array}{l}\text { Opinion on project } \\
\text { related subjects }\end{array}$ \\
\hline Eyes & $\begin{array}{l}\text { Contact data } \\
\text { (private) }\end{array}$ & Project aims & $\begin{array}{l}\text { Member of a } \\
\text { group since .. }\end{array}$ & Advertisement \\
\hline Hair & $\begin{array}{l}\text { Preferred medium } \\
\text { for contact during } \\
\text { project }\end{array}$ & Jobs finished & $\begin{array}{l}\text { Expertise } \\
\text { domain(s) }\end{array}$ & On my mind \\
\hline Body art & $\begin{array}{l}\text { Personal } \\
\text { assistant/secretary }\end{array}$ & Projects finished & $\begin{array}{l}\text { Motivation behind } \\
\text { expertise domain }\end{array}$ & Favorite spot \\
\hline $\begin{array}{l}\text { Daily eating } \\
\text { habits }\end{array}$ & Pets & Products finished & $\begin{array}{l}\text { Recent study or } \\
\text { work experience }\end{array}$ & $\begin{array}{l}\text { Sign of special } \\
\text { position in group } \\
\text { (e.g. ribbon) }\end{array}$ \\
\hline $\begin{array}{l}\text { Smoking } \\
\text { behavior }\end{array}$ & Situation at home & $\begin{array}{l}\text { Current } \\
\text { professional } \\
\text { activities (next to } \\
\text { project) }\end{array}$ & $\begin{array}{l}\text { Personal tip } \\
\text { (private) }\end{array}$ & $\begin{array}{l}\text { Sign of identity } \\
\text { verification }\end{array}$ \\
\hline $\begin{array}{l}\text { Drinking } \\
\text { behavior }\end{array}$ & Relation & $\begin{array}{l}\text { Current private } \\
\text { activities }\end{array}$ & $\begin{array}{l}\text { Personal tip (in } \\
\text { relation to } \\
\text { projects) }\end{array}$ & \\
\hline Informal video & $\begin{array}{l}\text { Availability } \\
\text { during project }\end{array}$ & $\begin{array}{l}\text { Expectation of } \\
\text { project }\end{array}$ & $\begin{array}{l}\text { Tip relevant } \\
\text { (re)source for } \\
\text { project }\end{array}$ & \\
\hline $\begin{array}{l}\text { Audio- } \\
\text { message for } \\
\text { project } \\
\text { members }\end{array}$ & $\begin{array}{l}\text { Project time } \\
\text { capacity }\end{array}$ & $\begin{array}{l}\text { Personal } \\
\text { motivation for } \\
\text { project }\end{array}$ & $\begin{array}{l}\text { Preference of role } \\
\text { within project }\end{array}$ & \\
\hline $\begin{array}{l}\text { Video- } \\
\text { message for } \\
\text { project } \\
\text { members }\end{array}$ & $\begin{array}{l}\text { Personal } \\
\text { description } \\
\text { "About me” }\end{array}$ & $\begin{array}{l}\text { Reason why you } \\
\text { are selected to } \\
\text { participate in } \\
\text { project }\end{array}$ & $\begin{array}{l}\text { Loves ... during } \\
\text { work }\end{array}$ & \\
\hline
\end{tabular}


Dynamic information (41 information elements)

\begin{tabular}{|c|c|c|c|c|}
\hline $\begin{array}{l}\text { Number of } \\
\text { made/changed/ } \\
\text { read/commented } \\
\text { messages/ } \\
\text { documents (by } \\
\text { profile owner) }\end{array}$ & $\begin{array}{l}\text { Received personal } \\
\text { rating of team } \\
\text { members }\end{array}$ & $\begin{array}{l}\text { Overview of } \\
\text { questions posed } \\
\text { by and answers } \\
\text { given to team } \\
\text { members }\end{array}$ & Items of friends & $\begin{array}{l}\text { Overlapping } \\
\text { interests and } \\
\text { expertise }\end{array}$ \\
\hline $\begin{array}{l}\text { Number of } \\
\text { seen/changed/com } \\
\text { mented } \\
\text { messages/docume } \\
\text { nts (by others) }\end{array}$ & $\begin{array}{l}\text { Rating given to } \\
\text { team members }\end{array}$ & $\begin{array}{l}\text { Local time at } \\
\text { location of team } \\
\text { member }\end{array}$ & Overlapping links & $\begin{array}{l}\text { Appointments } \\
\text { made and follow } \\
\text { up }\end{array}$ \\
\hline $\begin{array}{l}\text { Recently } \\
\text { made/changed/see } \\
\text { n documents }\end{array}$ & $\begin{array}{l}\text { Received } \\
\text { references/testimo } \\
\text { nials }\end{array}$ & $\begin{array}{l}\text { Last access date } \\
\text { and time }\end{array}$ & $\begin{array}{l}\text { Overlapping } \\
\text { references }\end{array}$ & $\begin{array}{l}\text { Given } \\
\text { reviews/testimonia } \\
\text { ls }\end{array}$ \\
\hline Contributions & $\begin{array}{l}\text { Received ratings } \\
\text { of } \\
\text { messages/contribu } \\
\text { tions }\end{array}$ & $\begin{array}{l}\text { Mean last acess } \\
\text { date and time }\end{array}$ & RSS feeds & $\begin{array}{l}\text { Received } \\
\text { reviews/testimonia } \\
\text { ls }\end{array}$ \\
\hline $\begin{array}{l}\text { Received } \\
\text { messages during } \\
\text { the last .. days }\end{array}$ & $\begin{array}{l}\text { Received personal } \\
\text { rating of team } \\
\text { members }\end{array}$ & Login frequency & $\begin{array}{l}\text { Percentage of } \\
\text { profile elements } \\
\text { filled by profile } \\
\text { owner }\end{array}$ & $\begin{array}{l}\text { Recommended by } \\
\text { team member x, } \\
\text { while .. }\end{array}$ \\
\hline $\begin{array}{l}\text { Mean response } \\
\text { time on messages }\end{array}$ & $\begin{array}{l}\text { Rating given to } \\
\text { team members }\end{array}$ & Online status & $\begin{array}{l}\text { Profile visit } \\
\text { frequency by team } \\
\text { members }\end{array}$ & \\
\hline $\begin{array}{l}\text { Response } \\
\text { percentage }\end{array}$ & $\begin{array}{l}\text { Received } \\
\text { references/testimo } \\
\text { nials }\end{array}$ & Agenda/diary & $\begin{array}{l}\text { Profile visit } \\
\text { frequency by } \\
\text { profile owner }\end{array}$ & \\
\hline $\begin{array}{l}\text { Given ratings of } \\
\text { messages/contribu } \\
\text { tions }\end{array}$ & $\begin{array}{l}\text { Given } \\
\text { references/testimo } \\
\text { nials }\end{array}$ & $\begin{array}{l}\text { Term frequency } \\
\text { within content of } \\
\text { messages/docume } \\
\text { nts }\end{array}$ & $\begin{array}{l}\text { Task list with all } \\
\text { deadlines, planned } \\
\text { and realized tasks } \\
\text { within project }\end{array}$ & \\
\hline $\begin{array}{l}\text { Received ratings } \\
\text { of } \\
\text { messages/contribu } \\
\text { tions }\end{array}$ & $\begin{array}{l}\text { Overview of } \\
\text { posed questions to } \\
\text { and answers of } \\
\text { team members }\end{array}$ & $\begin{array}{l}\text { Overview } \\
\text { overlapping } \\
\text { contacts with team } \\
\text { members }\end{array}$ & $\begin{array}{l}\text { Frequency of first, } \\
\text { second, third } \\
\text { authorship of } \\
\text { article/reports }\end{array}$ & \\
\hline
\end{tabular}

4. The ten most important information elements to have available in a profile to form a first impression of trustworthiness of a team member within the first two weeks of a project (open question).

5. Describe subsequently for each selected information element(open question):

- What are the facts you can derive from this information 
PREPRINT

- What is your interpretation of this information in relation to your impression of trustworthiness of your team members? What can you derive from this information leading to your trustworthiness impression?

6. Do you have any additional ideas regarding important information elements for the formation of a first impression of trustworthiness? (open question). 